\title{
In Vitro Screening for Antimicrobial Activity of Some Medicinal Plant Seed Extracts
}

\author{
Emad El Din G. Gomaa ${ }^{1}$, Naglaa M. Esmaiel ${ }^{2}$, Mohamed Z.M. Salem ${ }^{3}$ and \\ Sara E. Gomaa ${ }^{4, *}$
}

${ }^{1}$ Food Sci. and Technology Dept., Faculty of Agriculture, Alexandria University, Alexandria, Egypt

${ }^{2}$ Floriculture Dept, Horticulture Research Institute (HRI), Egypt

${ }^{3}$ Forestry and Wood Technology Dept., Faculty of Agriculture, Alexandria University, Alexandria, Egypt

${ }^{4}$ Veg., Medicinal and Aromatic Plants Breeding Dept., Horticulture Research Institute (HRI), Egypt

\begin{abstract}
Phytochemical screening (saponins, tannins, steroids, alkaloids, flavonoids, phenols and glycosides) of four medicinal plant seeds (Jatropha curcas, Simmondsia chinensis (Jojoba), Moringa oleifera and Datura metel) extracted by aqueous, ethanol and Folch solvents, were examined for their antimicrobial activity against three types of plant pathogenic fungi namely; Botrytis cinerea, Fusarium oxysporum and Rhizoctonia solani, in addition to four types of bacteria, namely; Bacillus cereus, Staphylococcus aureus, Ralstonia solanacearum and Pesudomonas aeruginosa using disc diffusion paper. Results revealed that different concentrations of aqueous extracts were more effective against bacterial activity compared to fungal activity, except for $D$. metel aqueous extract which showed no antifungal effect and very weak effect on only two of the tested bacteria. $B$. cereus was more sensitive to J. curcas aqueous extract, while $P$. aeruginosa was more sensitive to $S$. chinensis and $M$. oleifera aqueous extracts. On the other hand, results showed that $J$. curcas and $M$. oleifera ethanol extracts were more effective on Staph. aureus growth, while S. chinensis and $D$. metel did not have any effect on any of the fungi or bacteria under study. The evaluation of the antifungal and antibacterial effect did not confirm the broad spectrum of $S$. chinensis Folch extract, while M. oleifera and D. metel were more effective on reducing $R$. solani growth. Also $F$. oxysporum was affected by $J$. curcas Folch extract only at high concentrations. These findings support that the traditional use of the plant extracts in the treatment of different infections caused by pathogenic microbes is valuable and should be taken in consideration.
\end{abstract}

Keywords: Phytochemical screening, antimicrobial activities, Jatropha curcas, Simmondsia chinensis (Jojoba), Moringa oleifera, Datura metel.

\section{INTRODUCTION}

Under field conditions, pesticides have minor effect and are considered as a source of chemical pollution and a toxin of human diets [1]. Using these chemical pesticides for a long time, developed pathogens resistance towards pesticides and they became useless [2-4]. Plants and microbial tissues have defensive antibiotics and natural compounds against these pathogens [5-7]. Recently, many researchers have focused on the investigation of plant extracts and their uses as antimicrobial agent by nature. The fact that using plant extracts as traditional medicine continues to provide health converges for over $88 \%$ of the world's population, especially in the developing world [8]. The actions of these plants on microorganisms have been found to be due to the presence of phytochemical substance such as alkaloids, glycosides, volatile oils, gums, tannins, steroids, saponins, flavonoids and a host of other chemical compounds referred to as secondary

*Address correspondence to this author at the Veg., Medicinal and Aromatic Plants Breeding Dept., Horticulture Research Institute (HRI), Agriculture Research Center (ARC), Egypt; Tel: +2 01005214 955; Fax +203 5928294; E-mail: sara_gomaa@hotmail.com metabolites that are present in them [9-11]. According to further studies, phytochemical compounds in medicinal plants, which have antibacterial effect, provide information on nature extracts as inhibitory factors (microbiocidal or microbiostatic), and thier efficiency depends on the extracts solvent, concentration and cell damage inflicted to the tested microorganisms [8]. There are over thousands of varieties and species of medicinal plants used globally as antimicrobial agents and for curing different infections [12]. These plants include Jatropha curcas, which is believed to be a native of South America and Africa but later introduced to other continents of the world [13]. Many methods were used for J. curcas extraction from stem bark and roots to be used as an antimicrobial agent [14]. The ethanolic and aqueous extracts of $J$. curcas plant were analyzed phytochemically and screened against different microorganisms responsible for various human infections [15].

Simmondsia chinensis Schneider, commonly known as Jojoba, is a semi-arid evergreen shrub [16]. It grows in the desert of south-western United States and northwestern Mexico. However, this plant is cultivated in 
Australia, Brazil, Argentina and Middle East countries [17-18]. Jojoba is unique among plants in the fact that $50 \%$ of its seeds weight consists of oil. This oil contains quantities of sterols, stanols and different tocco phenols [19-20]. The ethanolic and aqueous extracts of S. chinensis root contained some phytochemical compounds like tannins, phenols and flavonoids, but void of alkaloids, glycosides and saponins [21]. Also, different parts of $S$. chinensis namely; testa, seeds, male and female leaves were extracted by soxhlet apparatus using ethanol and methanol. Results showed no activity against Staph. aureus, Bacillus subtilis, E. coli, Klebsiella pneumoniae and Candida albicans [22].

Moringa oleifera is a member of the family Moringaceae, native to Africa, South Asia, America, Himalayan region, India, Pakistan, and the pacific and Caribbean Islands [23]. Moringa plants provide a rich and rare combination of zeatin, quercetin, kaempferom and many other phytochemical compounds [24]. It was also studied for its antibiotic effect [25] and antimicrobial properties [26]. The phytochemical screening of $M$. oleifera leaf extracted by water and ethanol indicated the presence of flavonoids, steroids, alkaloids and saponins. Also, antifungal activity of ethanolic and aqueous extracts of $M$. oleifera leaf was highly active against some fungal strains [27]. $M$. oleifera seeds are rich in oil ß-carotene, plant sterols and lecithin, and also its oil contains unusual kinds of fatty acids [28]. In Sudan, powdered seeds have been used in water purification [29]: this powder also works as a natural coagulant, which clarifies very turbid water [30]. Reports have been elucidated on the findings of the antibiotic principle of $M$. oleifera seeds through their purification, and antimicrobial properties [31]. $M$. oleifera seeds extracted by aqueous, petroleum ether and methanol at different concentrations, inhibited growth of two species of fungi and four types of bacteria to varying degrees, but the aqueous extract was strong and superior on antibacterial activity especially Gram positive as compared to methanol or petroleum ether, while no activity was observed against some fungal strains [29]. The ethanolic extract of $M$. oleifera seeds was inhibitory to both Shigella flexneria and E. coli, while Salmonella typhi was not affected. Also, various concentration of the aqueous extract was inactive against the tested organisms [32].

Datura plant belongs to the family Solanaceae which is distributed worldwide and includes 85 genera and about 2800 species. There are approximately 25 different species of Datura throughout the world usually called as Jimson weed [33]. Datura leaves and seeds are widely used in herbal medicines as anesthetic, antispasmodic, antitussive, bronchiectasis and hallucinogenic [34]. Aqueous extracts of $D$. mete; roots, stems, leaves and seeds, were used as antibacterial agent against five human pathogens, each of the root and stem aq. extract was less effective on tested bacteria compared with leaf and seed extracts [35]. Leaf, stem and roots of $D$. metel were extracted by ethanol and water: aqueous extract contained all the phytochemical compounds, while tannins and steroids were absent in the ethanolic extract. $P$. aeruginosa and $S$. typhi were most inhibited by leaf and stem aqueous extract of $D$. metel, while leaf ethanolic extract demonstrated an inhibitory potency against $P$. aeruginosa, $K$. pneumoniae and $B$. cereus. Also, the root aqueous extract of the plant showed no antibacterial activity on all tested bacteria [36]. Some new antibacterial agent was isolated from $D$. metel leaves by ethanol using soxhlet apparatus at different concentrations, which successfully inhibited $P$. aeruginosa, B. subtilis, S. typhi, K. peneumonia, Staph. aureus and Proteus mirabl, but could not inhibit $E$. coli [37]. Leaves aqueous extract of $D$. metel contained all phytochemical compounds, except alkaloids, glycosides and phytosterols. This extract has an inhibitory activity against Flavobacterium psychrophilium, cold water bacteria, which causes some diseases at high concentration, while leaves chloroform extract has more inhibitory effect on these bacteria, but hexane extract showed less effect on bacterial growth at higher concentration [38]. This study aims to investigate the phytochemical content and evaluate the antibacterial and antifungal activity of $J$. curcas, S. chinensis, M. oleifera and $D$. metel using aqueous, ethanol and Folch seed extracts.

\section{MATERIALS AND METHODS}

\section{Source of Samples}

Four medicinal plant seeds were used in this study namely; Jatropha curcas, Simmondsia chinensis (Jojoba), Moringa oleifera and Datura metel, which were supplied by Orman herbarium garden, Agricultural Research Center (ARC), Cairo, Egypt, during year 2015. Seeds were grounded to pass through a 100 mesh sieve and stored in sealed glass bottles under dry and dark conditions at room temperature for latter extraction.

\section{Preparation of Extracts}

Aqueous extraction was made with some modifications [39]: $150 \mathrm{ml}$ of double distilled water was 
added to $25 \mathrm{~g}$ of the grounded seed samples in a flask, stirred, then flasks were sealed with aluminum foil and allowed to stand for $72 \mathrm{hrs}$ at room temperature. Ethanol extraction was done by mixing $25 \mathrm{~g}$ of grounded seeds with $150 \mathrm{ml}$ ethanol (95\%) for 7 days under shaking. Also, Folch extraction was done by extracting $25 \mathrm{~g}$ of grounded seeds with $150 \mathrm{ml}$ of Folch solvent (Chloroform : Methanol 2:1 v/v) for 24 hours at room temperature [40]. Extracted contents were then filtered with whatman No. 1 filter paper, then filtrates were concentrated using rotary evaporator (Yamato Scientific Ltd., RE 504, Japan; using pump, JEIO $\mathrm{TECH}, \mathrm{VE}-11$, Korea) at $40^{\circ} \mathrm{C}$ until dryness. Extracts were dissolved in $10 \%$ dimethyl sulfoxide (DMSO, Sigma-Aldrich, Co. 3050 spruce street, St. Louis, MO 63103 , USA) to make serial dilutions of extracts (250, 500, 1000, 2000 and 4000ppm) [41]. Concentrated extracts were stored at $4{ }^{\circ} \mathrm{C}$ in sealed glass bottles prior to use.

\section{Phytochemical Screening}

Simple qualitative phytochemical screening of the major groups of saponins, tannins, steroids, alkaloids, flavonoids, phenols and glycosides were tested according to standard methods [42-44].

\section{Collection, Maintenance and Enumeration of Organisms}

Three cultural strains of fungi and four cultural strains of bacteria used in this study, were kindly provided by Plant Pathogen Institute (PPI), Agriculture research center (ARC), Cairo, Egypt. Fungal strains namely; Botrytis cinerea (Gray rot), Fusarium oxysporum (Fusarium white wilt) and Rhizoctonia solani (Root rot), were grown on slant potato dextrose agar (PDA) at $24^{\circ} \mathrm{C}$ for 12 days until complete sporulation [45]. The slants were maintained under sterilized paraffin oil as stock culture. The spore suspension was obtained from slant agar with $0.1 \%$ peptone water. The number of spores was determined by indirect technique for cell count [46], one touch from pure colony was taken and added to $10 \mathrm{ml}$ peptone water, then dilutions were made (suspension solution), after that, $1 \mathrm{ml}$ from each dilution was added in petri dish and media was poured on the suspension. The number of spores from suspension solution was $4 \times 10^{6}$ spores $/ \mathrm{ml}$.

Bacterial strains used in present study included: Bacillus cereus, Staphylococcus aureus, Ralstonia solanacearum (Potato brown rot) and Pesudomonas aeruginosa, which were grown on slant nutrient agar
(NA) (Oxoid, 40, England) [45]. The same indirect technique was used for enumeration of colonies forming unit $(\mathrm{CFU} / \mathrm{ml})$ by making many dilutions where each one $\mathrm{ml}$ of suspension contains $10^{5}$ to $10^{6} \mathrm{CFU}$. The antibacterial potential of seed extracts was evaluated by disc paper diffusion [47-48].

\section{Antifungal and Antibacterial Tests}

$1 \mathrm{ml}$ of each fungal strain suspension was added to Petri dishes containing liquefied PDA $\left(45-50{ }^{\circ} \mathrm{C}\right)$. Also, $1 \mathrm{ml}$ of every bacterial strain was incubated in NA, after being solidified in Petri dishes ( $2 \mathrm{hrs}$ ). Filter paper discs $(5 \mathrm{~mm}$ ) whatman No. 3 containing $20 \mu \mathrm{l}$ from each concentration of seed extract were put on the media's surface. Plates containing PDA and NA were then incubated at $28{ }^{\circ} \mathrm{C}$ for $48 \mathrm{hr}$ and at $37{ }^{\circ} \mathrm{C}$ for $24 \mathrm{hrs}$ respectively, and the diameter of the inhibition zone (DIZ) was measured in $\mathrm{mm}$ and recorded. The inhibition zones obtained were compared with the positive control $(25 \mu \mathrm{l}$ of tetracycline $10 \mu \mathrm{g} / \mathrm{disc}$, cipla Itd, Mumbai, India) and the negative control disks were saturated with $20 \mu \mathrm{l}$ of $10 \%$ DMSO solution [41]. Minimum inhibitory concentrations (MICs) were determined by serial dilution of extracts $(250,500$, 1000,2000 and $4000 \mu \mathrm{g} / \mathrm{ml}$ ). Inhibition of the growth was indicated by a clear solution or a definite decrease in color reaction.

\section{RESULTS AND DISCUSSION}

Four medicinal plant seeds, extracted by three extraction methods, were used in this study to test their antimicrobial effect on 3 pathogenic fungi and four strains of bacteria.

\section{Phytochemical Screening of Extracts}

Table 1 showed simple qualitative phytochemical analysis of seed extracts for Jatropha curcas, Simmondsia chinensis (Jojoba), Moringa oleifera and Datura metel, were performed by three extraction methods. J. curcas aqueous extract had the highest amount of all phytochemical compounds; it was rich in glycosides content followed by flavonoids and phenols with no alkaloids. Ethanol and Folch extracts had a reduced amount of components than aqueous extract. Tannins and flavonoids were absent in ethanol extract and glycosides was absent in Folch extract. It was found that $J$. curcas ethanol stem extract contained saponins, tannins, cordic glycosides and flavonoids [14].

On the other hand, each of $S$. chinensis and $M$. oleifera aqueous extracts had more phenols than other 
Table 1: Simple Qualitative Phytochemical Analysis of Extracts from Seeds of Jatropha curcas, Simmondsia chinensis, Moringa oleifera and Datura metel

\begin{tabular}{|c|c|c|c|c|c|c|c|}
\hline J. curcas & Saponins & Tannins & Steroids & Alkaloids & Flavonoids & Phenols & Glycosides \\
\hline Aqueous extract & ++ & ++ & ++ & - & ++ & ++ & ++ \\
\hline Ethanol extract & + & - & + & + & - & + & + \\
\hline Folch extract & + & + & + & + & + & + & - \\
\hline S. chinensis & Saponins & Tannins & Steroids & Alkaloids & Flavonoids & Phenols & Glycosides \\
\hline Aqueous extract & - & ++ & - & - & ++ & ++ & - \\
\hline Ethanol extract & - & - & - & - & + & - & - \\
\hline Folch extract & - & - & + & - & + & - & - \\
\hline M. oleifera & Saponins & Tannins & Steroids & Alkaloids & Flavonoids & Phenols & Glycosides \\
\hline Aqueous extract & + & - & + & + & ++ & +++ & - \\
\hline Ethanol extract & ++ & ++ & ++ & ++ & ++ & ++ & - \\
\hline Folch extract & + & - & + & + & + & + & - \\
\hline D. metel & Saponins & Tannins & Steroids & Alkaloids & Flavonoids & Phenols & Glycosides \\
\hline Aqueous extract & + & + & + & + & + & + & + \\
\hline Ethanol extract & + & - & - & + & + & + & + \\
\hline Folch extract & + & - & + & + & + & - & - \\
\hline
\end{tabular}

$+=$ slightly present, $++=$ moderately present, $+++=$ highly present, - = absent.

phytochemical compounds, while glycosides was not detected in the three extracts of both plants. Also, most components were absent in ethanol and Floch extracts of $S$. chinensis seeds. Results in the same Table illustrated that only $D$. metel aqueous extract had all phytochemical compounds in fewer amounts than other aqueous extracts. Tannins were not detected in ethanol and Folch extracts, while phenols and glycosides were absent from Folch extract only. Such preliminary phytochemical screening is helpful in predicting drugs nature and useful for detecting different constituents in different polarity solvents as mentioned [21].

\section{Jatropha curcas Seed Extracts}

The diameter of inhibition zone (DIZ) in millimeters $(\mathrm{mm})$ at different concentrations of $J$. curcas seed extracts compared with tetracycline at $10 \mu$ las positive control, were demonstrated in Table 2. Results showed that, the inhibition of bacterial growth by aqueous extract was more than fungal growth inhibition at different concentrations. $B$. cereus was the most sensitive bacteria and was affected by this extract, followed by Staph. aureus at all concentrations, while $R$. solanacearum was less sensitive. $B$. cereus and Staph. aureus recorded DIZ 25.33 and $24.89 \mathrm{~mm}$ at the highest concentration, respectively, while $R$. solanacearum recorded $7.67 \mathrm{~mm}$ at the same concentration of $J$. curcas aq. extract. Also, fungal growth of $F$. oxysporum was affected $(21.0 \mathrm{~mm})$ followed by $R$. solani $(13.67 \mathrm{~mm})$ at the highest concentrations (4000ppm).

It worth mentioning that, $J$. curcas aqueous extract at $4000 \mathrm{ppm}$ had more effect on B. cereus, Staph. aureus and $F$. oxysporum growth than tetracycline (positive control), which recorded DIZ 20, 21, and $17 \mathrm{~mm}$, respectively. These results explain the effect of high amounts of phytochemical compounds in aqueous extract of J. curcas especially glycosides. J. curcas water and ethanol extraction from root was done [15, 49]. Results was that each of the alkaloids and tannins were present in all root extracts and the plants contained active compounds against microorganisms and inhibited the growth of all bacteria tested, except $P$. aeruginosa. Results in Tables $\mathbf{1}$ and $\mathbf{2}$ came in agreement with previous reports [15]. Also, it was observed that aqueous extract of $J$. curcas root was effective against Staph. aureus with $17 \mathrm{~mm}$ at $1.0 \mathrm{ml}$ $[15,50]$. J. curcas ethanol extract was found to be inactive against all the tested microorganisms used in this study except Staph. aureus, which recorded DIZ $10.67,10.00,7.67$ and $6.33 \mathrm{~mm}$ at $4000,2000,1000$ and 500ppm, respectively. Previous researches used the ethanol stem extract of J. curcas against Staph. aureus [14], they noted that this extract showed no 
significant difference in the zone of inhibition against Staph. aureus compared with the positive control ciprofloxacin. These results were revealed in the absence of tannins and flavonoides in ethanol extract beside the presence of little amount of phytochemical compounds (Tables 1 and 2). Also, tetracycline recorded $21 \mathrm{~mm}$ as a positive control with Staph. aureus.
The effect of aqueous and ethanol extracts from $\mathrm{J}$. curcas roots on some bacteria and fungi were studied [15]. It was found that ethanol extracts were rich in tannins, alkaloids, steroids and saponins, whereas aqueous extract contained the same phytochemical compounds but a lower level, therefore the ethanol extract has effect on Staph. aureus and $P$. aeruginosa growth at high concentrations, while aqueous extracts

Table 2: Antifungal and Antibacterial Activity of Jatropha curcas Seed Extracts

\begin{tabular}{|c|c|c|c|c|c|c|c|c|}
\hline \multirow{3}{*}{\multicolumn{2}{|c|}{ Strains }} & \multicolumn{5}{|c|}{ Aqueous extract (ppm) } & \multirow{3}{*}{ Tetracycline ${ }^{* *}$} & \multirow{3}{*}{ DMSO } \\
\hline & & 4000 & 2000 & 1000 & 500 & 250 & & \\
\hline & & \multicolumn{5}{|c|}{ Diameter of inhibition zone (DIZ mm)* } & & \\
\hline \multirow[t]{3}{*}{ Fungi } & Botrytis cinerea & - & - & - & - & - & 15 & - \\
\hline & Fusarium oxysporum & $21.00 \pm 1.41$ & $17.67 \pm 0.91$ & $14.00 \pm 0.97$ & $10.67 \pm 0.97$ & $5.67 \pm 0.84$ & 17 & - \\
\hline & Rhizoctonia solani & $13.67 \pm 0.69$ & $10.33 \pm 1.33$ & $7.67 \pm 0.91$ & $4.67 \pm 0.77$ & - & 14 & - \\
\hline \multirow[t]{4}{*}{ Bacteria } & Bacillus cereus & $25.33 \pm 0.59$ & $21.33 \pm 0.91$ & $15.00 \pm 0.77$ & $12.67 \pm 1.28$ & $8.33 \pm 1.08$ & 20 & - \\
\hline & Staphylococcus aureus & $24.89 \pm 1.37$ & $22.00 \pm 1.41$ & $14.35 \pm 0.97$ & $10.67 \pm 0.91$ & $8.00 \pm 0.97$ & 21 & - \\
\hline & Ralstonia solanacearum & $7.67 \pm 0.84$ & $2.67 \pm 0.77$ & - & - & - & 9 & - \\
\hline & $\begin{array}{c}\text { Pseudomonas } \\
\text { aeruginosa }\end{array}$ & - & - & - & - & - & 26 & - \\
\hline & \multirow{3}{*}{ Strains } & \multicolumn{5}{|c|}{ Ethanol extract (ppm) } & \multirow{3}{*}{ Tetracycline ${ }^{* *}$} & \multirow{3}{*}{ DMSO } \\
\hline & & 4000 & 2000 & 1000 & 500 & 250 & & \\
\hline & & & Diameter of & hibition zon & $(\mathrm{DIZ} \mathrm{mm})^{*}$ & & & \\
\hline \multirow[t]{3}{*}{ Fungi } & Botrytis cinerea & - & - & - & - & - & 15 & - \\
\hline & Fusarium oxysporum & - & - & - & - & - & 17 & - \\
\hline & Rhizoctonia solani & - & - & - & - & - & 14 & - \\
\hline \multirow[t]{4}{*}{ Bacteria } & Bacillus cereus & - & - & - & - & - & 20 & - \\
\hline & Staphylococcus aureus & $10.67 \pm 0.91$ & $10.00 \pm 0.69$ & $7.67 \pm 0.49$ & $6.33 \pm 0.77$ & - & 21 & - \\
\hline & Ralstonia solanacearum & - & - & - & - & - & 9 & - \\
\hline & $\begin{array}{c}\text { Pseudomonas } \\
\text { aeruginosa }\end{array}$ & - & - & - & - & - & 26 & - \\
\hline \multirow{3}{*}{\multicolumn{2}{|c|}{ Strains }} & \multicolumn{5}{|c|}{ Folch extract (ppm) } & \multirow{3}{*}{ Tetracycline ${ }^{* *}$} & \multirow{3}{*}{ DMSO } \\
\hline & & 4000 & 2000 & 1000 & 500 & 250 & & \\
\hline & & & Diameter of & hibition zon & $(\mathrm{DIZ} \mathrm{mm})^{*}$ & & & \\
\hline \multirow[t]{3}{*}{ Fungi } & Botrytis cinerea & - & - & - & - & - & 15 & - \\
\hline & \multirow{2}{*}{$\begin{array}{l}\text { Fusarium oxysporum } \\
\text { Rhizoctonia solani }\end{array}$} & $13.33 \pm 0.69$ & $10.67 \pm 0.91$ & $8.33 \pm 0.97$ & - & - & 17 & - \\
\hline & & $7.67 \pm 0.77$ & $3.67 \pm 0.59$ & - & - & - & 14 & - \\
\hline \multirow[t]{4}{*}{ Bacteria } & Bacillus cereus & - & - & - & - & - & 20 & - \\
\hline & Staphylococcus aureus & - & - & - & - & - & 21 & - \\
\hline & Ralstonia solanacearum & - & - & - & - & - & 9 & - \\
\hline & $\begin{array}{c}\text { Pseudomonas } \\
\text { aeruginosa }\end{array}$ & - & - & - & - & - & 26 & - \\
\hline
\end{tabular}

*: Diameter of inhibition zone (DIZ mm) including disc diameter of $4 \mathrm{~mm}$.

**: Diameter of inhibition zone $(\mathrm{mm})$ observed by tetracycline as a positive control $(10 \mu \mathrm{g} / \mathrm{disc})$.

-. Not active.

DMSO: Dimethyl sulfoxide [( $\mathrm{CH} 3) 2 \mathrm{SO}]$ as a negative control.

Inhibition > $15 \mathrm{~mm}$ (strong inhibition), $15-10 \mathrm{~mm}$ (moderate), and <10 $\mathrm{mm}$ (weak). 
have no effect on only Staph. aureus at various concentrations.

$J$. curcas Folch extract affects the growth of two fungi only, F. oxysporum and $R$. solani up to 1000 and 2000 ppm, respectively, while it did not show any antibacterial effect. These results may be due to the low level of phytochemical compounds and the lack of others like glycosides.

\section{Simmondsia chinensis (Jojoba) Seed Extracts}

Results in Table 3 revealed that $S$. chinensis aqueous extract had an effect against only one fungus

Table 3: Antifungal and Antibacterial Activity of Simmondsia chinensis Seed Extracts

\begin{tabular}{|c|c|c|c|c|c|c|c|c|}
\hline & \multirow{3}{*}{ Strains } & \multicolumn{5}{|c|}{ Aqueous extract (ppm) } & \multirow{3}{*}{ Tetracycline** } & \multirow{3}{*}{ DMSO } \\
\hline & & 4000 & 2000 & 1000 & 500 & 250 & & \\
\hline & & \multicolumn{5}{|c|}{ Diameter of inhibition zone (DIZ mm)* } & & \\
\hline \multirow[t]{3}{*}{ Fungi } & Botrytis cinerea & - & - & - & - & - & 15 & - \\
\hline & Fusarium oxysporum & $17.00 \pm 1.08$ & $12.33 \pm 1.33$ & $8.67 \pm 1.08$ & $4.00 \pm 1.14$ & - & 17 & - \\
\hline & Rhizoctonia solani & - & - & - & - & - & 14 & - \\
\hline \multirow[t]{4}{*}{ Bacteria } & Bacillus cereus & $15.00 \pm 0.69$ & $12.33 \pm 0.97$ & $8.00 \pm 0.77$ & $5.67 \pm 0.84$ & - & 20 & - \\
\hline & $\begin{array}{c}\text { Staphylococcus } \\
\text { aureus }\end{array}$ & $19.67 \pm 0.97$ & $15.39 \pm 1.24$ & $10.48 \pm 1.15$ & $4.94 \pm 0.24$ & - & 21 & - \\
\hline & $\begin{array}{c}\text { Ralstonia } \\
\text { solanacearum }\end{array}$ & - & - & - & - & - & 9 & - \\
\hline & $\begin{array}{c}\text { Pseudomonas } \\
\text { aeruginosa }\end{array}$ & $32.33 \pm 0.59$ & $25.33 \pm 1.03$ & $19.87 \pm 1.57$ & $11.40 \pm 1.09$ & $5.32 \pm 0.77$ & 26 & - \\
\hline & \multirow{3}{*}{ Strains } & \multicolumn{5}{|c|}{ Ethanol extract (ppm) } & \multirow{3}{*}{ Tetracycline** } & \multirow{3}{*}{ DMSO } \\
\hline & & 4000 & 2000 & 1000 & 500 & 250 & & \\
\hline & & & Diameter o & hibition zon & IZ mm)* & & & \\
\hline \multirow[t]{3}{*}{ Fungi } & Botrytis cinerea & - & - & - & - & - & 15 & - \\
\hline & Fusarium oxysporum & - & - & - & - & - & 17 & - \\
\hline & Rhizoctonia solani & - & - & - & - & - & 14 & - \\
\hline \multirow[t]{4}{*}{ Bacteria } & Bacillus cereus & - & - & - & - & - & 20 & - \\
\hline & $\begin{array}{c}\text { Staphylococcus } \\
\text { aureus }\end{array}$ & - & - & - & - & - & 21 & - \\
\hline & $\begin{array}{c}\text { Ralstonia } \\
\text { solanacearum }\end{array}$ & - & - & - & - & - & 9 & - \\
\hline & $\begin{array}{c}\text { Pseudomonas } \\
\text { aeruginosa }\end{array}$ & - & - & - & - & - & 26 & - \\
\hline & \multirow{3}{*}{ Strains } & \multicolumn{5}{|c|}{ Folch extract (ppm) } & \multirow{3}{*}{ Tetracycline** } & \multirow{3}{*}{ DMSO } \\
\hline & & 4000 & 2000 & 1000 & 500 & 250 & & \\
\hline & & \multicolumn{5}{|c|}{ Diameter of inhibition zone (DIZ mm)* } & & \\
\hline \multirow[t]{3}{*}{ Fungi } & Botrytis cinerea & - & - & - & - & - & 15 & - \\
\hline & \multirow{2}{*}{$\begin{array}{c}\text { Fusarium oxysporum } \\
\text { Rhizoctonia solani }\end{array}$} & - & - & - & - & - & 17 & - \\
\hline & & - & - & - & - & - & 14 & - \\
\hline \multirow[t]{4}{*}{ Bacteria } & Bacillus cereus & - & - & - & - & - & 20 & - \\
\hline & $\begin{array}{c}\text { Staphylococcus } \\
\text { aureus }\end{array}$ & - & - & - & - & - & 21 & - \\
\hline & $\begin{array}{c}\text { Ralstonia } \\
\text { solanacearum }\end{array}$ & - & - & - & - & - & 9 & - \\
\hline & $\begin{array}{c}\text { Pseudomonas } \\
\text { aeruginosa }\end{array}$ & - & - & - & - & - & 26 & - \\
\hline
\end{tabular}

*: Diameter of inhibition zone (DIZ mm) including disc diameter of $4 \mathrm{~mm}$.

**: Diameter of inhibition zone $(\mathrm{mm})$ observed by tetracycline as a positive control $(10 \mu \mathrm{g} / \mathrm{disc})$.

-. Not active.

DMSO: Dimethyl sulfoxide [( $\mathrm{CH} 3) 2 \mathrm{SO}]$ as a negative control.

Inhibition > $15 \mathrm{~mm}$ (strong inhibition), $15-10 \mathrm{~mm}$ (moderate), and <10 mm (weak). 
and three bacterial strains. At the highest concentration of aqueous extract, F. oxysporum recorded DIZ 17.00 $\mathrm{mm}$, while $B$. cereus, Staph. aureus and $P$. aeruginosa recorded DIZ 15.00, 19.67 and $32.33 \mathrm{~mm}$, respectively. Results illustrated that the increased concentration of $S$. chinensis aqueous extract decreased the growth of microorganisms tested. On the other hand the phytochemical compounds in $S$. chinensis aqueous extract were mostly absent except tannins, flavonoids and phenols which were present in high levels (Table 1). Therefore, this extract has less effect on microbial growth compared with $J$. curcas aqueous extract (Tables 2 and $\mathbf{3}$ ).

Results in other researches [21] came in agreement with the results obtained in Table 1, where it was found that water extract of $S$. chinensis root contains tannins, phenols and flavonoids but is void of alkaloids, steroids and saponins, while ethanol root extract contained the same phytochemical compounds of ethanol seed extract for tannins and phenols only.

Also, Table 3 showed no effect of both S. chinensis ethanol and Folch extracts on all tested microorganisms due to the absence of the major phytochemical compounds in these extracts especially tannins and phenols.

The $S$. chinensis ethanol extract had no activity against many kinds of microorganisms including Staph. aureus at different concentrations (Al. Oizwini et al., 2014). These results came in agreement with results obtained in Table 3.

\section{Moringa oleifera Seed Extracts}

Concerning $M$. oleifera aqueous extract, results in Table 4 showed that, the DIZ of $B$. cereus were 18.23 , $15.98,12.20$ and $8.07 \mathrm{~mm}$. Similarly $R$. solani had DIZ of $15.33,14.39,11.54$ and $7.4 \mathrm{~mm}$ for fungal strains at concentrations of 4000, 2000, 1000 and 500 ppm, respectively. Meanwhile $F$. oxysporum was not affected by $1000 \mathrm{ppm}$ concentration. Staph. aureus and $R$. solanacearum were unaffected by all the concentrations of aqueous extract with no zones of inhibition compared with positive control antibiotic, but $P$. aeruginosa was more sensitive to aqueous extract at all concentrations. It recorded DIZ 29.67, 19.67, 11.33, 9.00 and $6.33 \mathrm{~mm}$, while $B$. cereus was the least microbe tested affected by this extract. The presence of high levels of flavonoids and phenols in $M$. oleifera aqueous extract was more effective on growth of all fungi, in addition to $P$. aeruginosa (Tables 1 and $\mathbf{4}$ ). It was previously mentioned that, the flavonoids were known to be biologically active against liver toxins, viruses and other microbes [51]. Also, others found that, $M$. oleifera aqueous seed extract was strong and superior to antibacterial activity against Staph. aureus and $P$. aeruginosa [29], these results came in agreement with the results obtained in this study except for Staph. aureus.

On the other side, results of $M$. oleifera ethanol extracted had no effect on $B$. cereus and $R$. solani growth within all concentrations. Also, it had no effect on F. oxysporum along 500 ppm. As for Staph. aureus, it was more sensitive to ethanol extract at all concentration levels. The DIZ recorded 20.33, 18.33, $15.00,10.33$ and $8.00 \mathrm{~mm}$ followed by $B$. cereus $(14.67,13.33,9.67$ and 8.33 at 4000 to $500 \mathrm{ppm})$. $P$. aeruginosa was the least bacterium affected by ethanol extract. With reference to results in Table 1, ethanol extract contained the highest amounts of all phytochemical compounds except glycosides which were absent, that may explain the effectiveness of ethanol extract on bacteria rather than fungi. Earlier, it was found that $M$. oleifera aqueous extract had no effect on the tested organisms at various concentrations but there was appreciable antimicrobial activity demonstrated by the ethanol extract with $E$. coll and Shigella flexneri being susceptible, while S. typhi showed no susceptibility to both extracts[32]. Others used methanolic and aqueous extracts of $M$. oleifera seeds and found considerable effect on bacteria isolated from wound infections including $E$. coli.. Therefore, they reported that the extracts had broad spectrum of activity [52]. Also, researchers reported that $M$. oleifera ethanol extract have high antibacterial activity against $S$. typhi while the aqueous extract had low activity against the same organism [53]. Nevertheless results in this study illustrated that $M$. oleifera aqueous extract had effect on all tested fungi till $2000 \mathrm{ppm}$ and an even stronger effect on bacteria $B$. cereus and $P$. aeruginosa until 1000 and 250 ppm, respectively. In addition, $M$. oleifera ethanol extract inhibited the growth on only one fungi and three bacteria namely; $B$. cereus, Staph. aureus and $P$. aeruginosa.

Results in Table 4 showed that all fungi and bacteria tested were not affected by $M$. oleifera Folch extract except for $R$. solani and $P$. aeruginosa. $R$. solani with DIZ recorded 24.33 and $19.21 \mathrm{~mm}$ at 4000 and $2000 \mathrm{ppm}$, respectively compared with the positive control (tetracycline) which was $14 \mathrm{~mm}$. 
Table 4: Antifungal and Antibacterial Activity of Moringa oleifera Seed Extracts

\begin{tabular}{|c|c|c|c|c|c|c|c|c|}
\hline & \multirow{3}{*}{ Strains } & \multicolumn{5}{|c|}{ Aqueous extract (ppm) } & \multirow{3}{*}{ Tetracycline ${ }^{* *}$} & \multirow{3}{*}{ DMSO } \\
\hline & & 4000 & 2000 & 1000 & 500 & 250 & & \\
\hline & & \multicolumn{5}{|c|}{ Diameter of inhibition zone (DIZ mm)* } & & \\
\hline Fungi & $\begin{array}{l}\text { Fusarium } \\
\text { oxysporum }\end{array}$ & $17.00 \pm 0.59$ & $8.22 \pm 0.88$ & - & - & - & 17 & - \\
\hline \multirow[t]{3}{*}{ Bacteria } & Bacillus cereus & $9.00 \pm 0.49$ & $6.32 \pm 1.08$ & $2.76 \pm 0.65$ & - & - & 20 & - \\
\hline & $\begin{array}{c}\text { Staphylococcus } \\
\text { aureus }\end{array}$ & - & - & - & - & - & 21 & - \\
\hline & $\begin{array}{c}\text { Ralstonia } \\
\text { solanacearum }\end{array}$ & - & - & - & - & - & 9 & - \\
\hline & Strains & \multicolumn{5}{|c|}{ Diameter of inhibition zone (DIZ mm)* } & Tetracycline $^{* *}$ & DMSO \\
\hline \multirow[t]{3}{*}{ Fungi } & Botrytis cinerea & - & - & - & - & - & 15 & - \\
\hline & $\begin{array}{l}\text { Fusarium } \\
\text { oxysporum }\end{array}$ & $14.33 \pm 0.91$ & $11.33 \pm 0.84$ & $7.33 \pm 0.91$ & - & - & 17 & - \\
\hline & Rhizoctonia solani & - & - & - & - & - & 14 & - \\
\hline \multirow[t]{3}{*}{ Bacteria } & Bacillus cereus & $14.67 \pm 1.14$ & $13.33 \pm 1.19$ & $9.67 \pm 0.91$ & $8.33 \pm 1.08$ & - & 20 & - \\
\hline & $\begin{array}{c}\text { Staphylococcus } \\
\text { aureus }\end{array}$ & $20.33 \pm 0.49$ & $18.33 \pm 1.53$ & $15.00 \pm 0.77$ & $10.33 \pm 0.77$ & $8.00 \pm 0.69$ & 21 & - \\
\hline & $\begin{array}{c}\text { Ralstonia } \\
\text { solanacearum }\end{array}$ & - & - & - & - & - & 9 & - \\
\hline \multirow[t]{3}{*}{ Fungi } & Botrytis cinerea & - & - & - & - & - & 15 & - \\
\hline & \multirow{2}{*}{$\begin{array}{c}\text { Fusarium } \\
\text { oxysporum } \\
\text { Rhizoctonia solani }\end{array}$} & - & - & - & - & - & 17 & - \\
\hline & & $24.33 \pm 1.85$ & $19.21 \pm 0.81$ & $13.54 \pm 0.98$ & $9.02 \pm 0.34$ & $2.00 \pm 0.84$ & 14 & - \\
\hline \multirow[t]{4}{*}{ Bacteria } & Bacillus cereus & - & - & - & - & - & 20 & - \\
\hline & $\begin{array}{c}\text { Staphylococcus } \\
\text { aureus }\end{array}$ & - & - & - & - & - & 21 & - \\
\hline & $\begin{array}{c}\text { Ralstonia } \\
\text { solanacearum }\end{array}$ & - & - & - & - & - & 9 & - \\
\hline & $\begin{array}{c}\text { Pseudomonas } \\
\text { aeruginosa }\end{array}$ & $18.33 \pm 0.69$ & $15.00 \pm 0.69$ & $10.67 \pm 0.84$ & $7.67 \pm 0.49$ & - & 26 & - \\
\hline
\end{tabular}

*: Diameter of inhibition zone (DIZ mm) including disc diameter of $4 \mathrm{~mm}$.

**: Diameter of inhibition zone $(\mathrm{mm})$ observed by tetracycline as a positive control $(10 \mu \mathrm{g} / \mathrm{disc})$.

-. Not active.

DMSO: Dimethyl sulfoxide [(CH3)2SO] as a negative control.

Inhibition > $15 \mathrm{~mm}$ (strong inhibition), $15-10 \mathrm{~mm}$ (moderate), and <10 $\mathrm{mm}$ (weak).

\section{Datura metel Seed Extracts}

Extracts of Datura spp. were known for their phytochemical compounds which affect antibacterial activity beside their use against diseases caused by some pathogenic bacteria [35-39]. D. metel aqueous extract contained all the phytochemical compounds but in decreased levels compared with other extracts under 
Table 5: Antifungal and Antibacterial Activity of Datura metel Seed Extracts

\begin{tabular}{|c|c|c|c|c|c|c|c|c|}
\hline & \multirow{3}{*}{ Strains } & \multicolumn{5}{|c|}{ Aqueous extract (ppm) } & \multirow{3}{*}{ Tetracycline** $^{\star *}$} & \multirow{3}{*}{ DMSO } \\
\hline & & 4000 & 2000 & 1000 & 500 & 250 & & \\
\hline & & \multicolumn{5}{|c|}{ Diameter of inhibition zone (DIZ mm)* } & & \\
\hline \multirow[t]{3}{*}{ Fungi } & Botrytis cinerea & - & - & - & - & - & 15 & - \\
\hline & Fusarium oxysporum & - & - & - & - & - & 17 & - \\
\hline & Rhizoctonia solani & - & - & - & - & - & 14 & - \\
\hline \multirow[t]{4}{*}{ Bacteria } & Bacillus cereus & - & - & - & - & - & 20 & - \\
\hline & Staphylococcus aureus & $7.00 \pm 1.19$ & $3.75 \pm 0.73$ & $0.80 \pm 0.55$ & - & - & 21 & - \\
\hline & Ralstonia solanacearum & - & - & - & - & - & 9 & - \\
\hline & Pseudomonas aeruginosa & $8.52 \pm 0.40$ & $6.22 \pm 0.88$ & - & - & - & 26 & - \\
\hline & \multirow{3}{*}{ Strains } & & Ethanol & tract (ppm) & & & \multirow{3}{*}{ Tetracycline** } & \multirow{3}{*}{ DMSO } \\
\hline & & 4000 & 2000 & 1000 & 500 & 250 & & \\
\hline & & \multicolumn{5}{|c|}{ Diameter of inhibition zone (DIZ mm)* } & & \\
\hline \multirow[t]{3}{*}{ Fungi } & Botrytis cinerea & - & - & - & - & - & 15 & - \\
\hline & Fusarium oxysporum & - & - & - & - & - & 17 & - \\
\hline & Rhizoctonia solani & - & - & - & - & - & 14 & - \\
\hline \multirow[t]{4}{*}{ Bacteria } & Bacillus cereus & - & - & - & - & - & 20 & - \\
\hline & Staphylococcus aureus & - & - & - & - & - & 21 & - \\
\hline & Ralstonia solanacearum & - & - & - & - & - & 9 & - \\
\hline & Pseudomonas aeruginosa & - & - & - & - & - & 26 & - \\
\hline & \multirow{3}{*}{ Strains } & \multicolumn{5}{|c|}{ Folch extract (ppm) } & \multirow{3}{*}{ Tetracycline ${ }^{\star *}$} & \multirow{3}{*}{ DMSO } \\
\hline & & 4000 & 2000 & 1000 & 500 & 250 & & \\
\hline & & \multicolumn{5}{|c|}{ Diameter of inhibition zone (DIZ mm)* } & & \\
\hline \multirow[t]{3}{*}{ Fungi } & Botrytis cinerea & - & - & - & - & - & 15 & - \\
\hline & \multirow{2}{*}{$\begin{array}{c}\text { Fusarium oxysporum } \\
\text { Rhizoctonia solani }\end{array}$} & - & - & - & - & - & 17 & - \\
\hline & & $12.00 \pm 0.77$ & $9.00 \pm 0.59$ & $4.84 \pm 0.62$ & - & - & 14 & - \\
\hline \multirow[t]{4}{*}{ Bacteria } & Bacillus cereus & - & - & - & - & - & 20 & - \\
\hline & Staphylococcus aureus & - & - & - & - & - & 21 & - \\
\hline & Ralstonia solanacearum & - & - & - & - & - & 9 & - \\
\hline & Pseudomonas aeruginosa & - & - & - & - & - & 26 & - \\
\hline
\end{tabular}

*: Diameter of inhibition zone (DIZ mm) including disc diameter of $4 \mathrm{~mm}$.

**: Diameter of inhibition zone $(\mathrm{mm})$ observed by tetracycline as a positive control $(10 \mu \mathrm{g} / \mathrm{disc})$.

-. Not active.

DMSO: Dimethyl sulfoxide $[(\mathrm{CH} 3) 2 \mathrm{SO}]$ as a negative control.

Inhibition > $15 \mathrm{~mm}$ (strong inhibition), 15 - $10 \mathrm{~mm}$ (moderate), and <10 mm (weak).

study (Table 1). Therefore, this extract had no effect on fungi growth, but it affected bacterial strains in weak inhibitory zones. Table 5 illustrated that the only two bacterial strains inhibited were Staph. aureus which recorded DIZ $7.00,3.75$ and $0.80 \mathrm{~mm}$ at 4000,2000 and $1000 \mathrm{ppm}$, respectively, and $P$. aeruginosa which recorded DIZ of 8.52 and $6.22 \mathrm{~mm}$ at 4000 and 2000 ppm respectively, while DIZ was $26 \mathrm{~mm}$ as displayed by tetracycline (positive control antibiotic). It was mentioned that, $D$. metel aqueous seed extract was effective against Staph. aureus, it showed inhibition of
14 and $17 \mathrm{~mm}$ at the concentrations of $50 \mu \mathrm{l}$ and $100 \mu \mathrm{l}$, respectively [35]. It was clear from Table 5 that $D$. metel ethanol extract had no effect on all tested microorganisms. This might be due to the absence of tannins and steroids. The remnant phytochemical components were found also in low levels (Table 1). It was found that, Staph. aureus was one of the weakest bacteria affected by $D$. metel ethanol leaf extract [37]. These results agreed with ethanol seed extract used in this study. 
Folch seed extract had effect only on one fungal strain, R. solani, at concentrations 4000,2000 and 1000 ppm, with DIZ 12.00, 9.00 and $4.84 \mathrm{~mm}$, respectively, compared with positive control which was $14 \mathrm{~mm}$ at $10 \mu \mathrm{l}$ of tetracycline (Table 5 ).

\section{CONCLUSION}

Results in this study revealed finally that aqueous seed extracts of Jatropha curcas and Simmondsia chinensis exhibited high degree of antibacterial and antifungal activities compared with ethanolic and Folch extracts, while aqueous and ethanol seed extracts of Moringa oleifera had more activities against bacterial and fungal growth. Seed extract of Datura metel showed no effect on all tested microorganisms. These results can be attributed to the presence of some phytochemical compounds in these extracts. Results in this work confirmed greatly that seeds of $J$. curacas, $S$. chinensis and $M$. oleifera can be used as an antibacterial and antifungal agent against the tested micro-organisms.

\section{ACKNOWLEDGMENTS}

The authors would like to thank the collaboration between the Faculty of Agriculture, Alexandria University, Egypt and the Horticulture Research Institute, Egypt.

\section{REFERENCES}

[1] Tantawy STA. Biological potential of cyanobacterial metabolites against some soil pathogenic fungi. J Food Agri Envir 2011; 9(1): 663-666.

[2] Peret AL, Naghetini, CC, Nunan EA, Junqueira RG, Glorias MBA. In vitro antimicrobial activity of the rhizome powder of curcuminoids pigments and essential oils of Curcuma Longa L. Sci Agr Lav 2008; 32(3): 875-881.

[3] Belewa V, Baijnath $\mathrm{H}$, Somai BM. Aqueous extracts from the bulbs of Tulbaghia violacea are antifungal against Aspergillus flavus. J Food Safety 2011; 31(2): 176-184. http://dx.doi.org/10.1111/j.1745-4565.2010.00282.x

[4] Medeiros RTS, Goncalez E. Felicio RC, Felicio JD Evaluation of antifungal activity of Pittosporum undulatum $\mathrm{L}$. essential oil against Aspergillus flavus and aflatoxin production. Sci Agrotec Lavras 2011; 35(1): 71-76. http://dx.doi.org/10.1590/S1413-70542011000100008

[5] Oliveira MS, Badiale-Furlong E. Screening of antifungal and antimycotoxigenic activity of plant phenolic extracts. World Mycotoxin J 2008; 1: 1-10. http://dx.doi.org/10.3920/WMJ2008.1006

[6] Ahmadi F. Chemical composition, in vitro antimicrobial, antifungal and antioxidant activities of the essential oil and methanolic extract of Hymenocrater longiflorus of Iran. Food Chem Toxi, Richmond 2010; 48: 1137-1144. http://dx.doi.org/10.1016/j.fct.2010.01.028

[7] Souza MM. Antifungal activity evaluation in phenolic extracts from onion, rice bran, and Chlorella pyrenoidosa. Food Sci Technol (Campinas) 2010; 30(3): 680-685. http://dx.doi.org/10.1590/S0101-20612010000300018
WHO. Traditional Medicine: Growing Needs and Potentials. Policy Perspectives on Medicines. World Health Organization, Geneva 2002; 1-6.

[9] Kochlar SL. Tropical Crops. In: A text book of Economic Botany. Macmillan Pub Ltd, London and Basing stroke 1986 21(25): 33-34.

[10] Sofowora EA. Medicinal Plants and Traditional Medicine in African. Spectrum Borks Ltd, Ibadan Nigeria 1982; p. 289.

[11] Oyagade JO, Awotoye OO, Adewumi JI, Thorpe HT. Antimicrobial Activities of some Nigerian medicinal plants: Screening for antimicrobial activity. Bros Res Com 1991; 11(3): 193-197.

[12] Omotayo AE. Antibacterial activity of some antimalarial plants. Proc Nig Soci Microbi 1998; 39: 69-72.

[13] Gubtiz GM, Mittelbach M, Trabi M. Exploitation of the tropical oil seed plant Jatropha curcas L. Bio Res Tech 1999; (67): 37-82.

[14] Wakirwa JH, Ibrahim P, Madu SJ. Phytochemical screening and in vitro antimicrobial analysis of the ethanol stem bark extract of Jatropha curcas Linn (Euphorbiaceae). Int Res J Pharma 2013; 4(3): 97-100.

http://dx.doi.org/10.7897/2230-8407.04317

[15] Arekemase MO, Kayode RM, Ajiboye AE. Antimicrobial activity and phytochemical analysis of Jatropha curca plant against some selected microorganisms. Int J Biol 2011; 3(3): 52-59 http://dx.doi.org/10.5539/ijb.v3n3p52

[16] Harry-O'Kura RE, Mohamed A, Abott TP. Synthesis and characterization of tetrahydroxy-jojoba wax and Ferulates of jojoba oil. Indust Crops Prod 2005; (22): 125-133. http://dx.doi.org/10.1016/j.indcrop.2004.07.001

[17] Davidson S. Jojoba: cautious optimism. Rural Res 1983; (119): 21-25.

[18] Borlaug M, Baldwin AR, Estefan R, Harris M, Plucknett DL. Jojoba new crop for arid lands, new raw material for industry. Nat Acad Press, Washington 1985; 6-13.

[19] Tada A, Jin ZL, Sugimoto M, Sato K, Yamazaki T, Tananoto $\mathrm{K}$. Analysis of the constituents in jojoba wax used as a food additive by LC/MS/MS. J. Food Hygen Soc. Japan 2005; 46(5): 198-204. http://dx.doi.org/10.3358/shokueishi.46.198

[20] El-Mallah MH, El-Shami SM. Investigation of liquid wax components of Egyptian Jojoba seeds. J Oleo Sci 2009; 58(11): 543-548. http://dx.doi.org/10.5650/jos.58.543

[21] Sharma SK, Singh AP. Pharmacognostical evaluation of roots of Simmondsia chinensis. Inter J Pharma Sci Drug Res 2011; 3(4): 323-326.

[22] Al Oizwini H, Al-Khateeb E, Mhaidat N, Maraqa A Antioxidant and antimicrobial activities of Jordanian Simmondsia chinensis (Link) CK Schneid. Euro Sci J 2014; 10(27): 229-241.

[23] Julia C. A study of nutritional and medicinal values of Moringa oleifera leaves from sub-saharan Africa Ghana, Rowanda Senegal and Zambia 2008.

[24] Pal SK, Mukherjee PK ,Saha BP. Studies on the antiulcer activity of Moringa oleifera leaf extract on gastric ulcer models in rats. Phyto Res 1995; 9: 463-465. http://dx.doi.org/10.1002/ptr.2650090618

[25] Eilert U, Wolters B, Nahrstedt A. The Antibiotic principles of seeds of Moringa oleifera and Moringa stenopetala. J Med PI 1981; 42(1): 55-61. http://dx.doi.org/10.1055/s-2007-971546

[26] Palaniswamy U. Purslane-Drumsticks, Lokavani 2004; 1: 23 25

[27] Patel P, Patel M, Patel D, Desai S, Meshram D. Phytochemical analysis and antifungal activity of Moringa oleifera. Int J Pharm Pharmac Sci 2014; 5(6): 144-147. 
[28] Shaheen F, Siddigui BS, Saleen R, Aftab K, Gilani A. Hypotensive constituents from the pods of $M$. oleifera. Planta Medica 1998; 64: 225-228. http://dx.doi.org/10.1055/s-2006-957414

[29] Saadabi AM, Abu Zaid. An In vitro Antimicrobial Activity of Moringa oleifera L. seed extracts against different groups of microorganisms. Aust J Bas Appl Sci 2011; 5(5): 129-134.

[30] Broin M, Santeanella C, Cuine S, Koukon S, Pellier G, Joet $\mathrm{T}$. Flocculant activity of a recombinant protein from Moringa oleifera. Appl Micr Biotech 2002; 60: 114-119. http://dx.doi.org/10.1007/s00253-002-1106-5

[31] Jamil A, Shahid M, Khan MM, Ashraf A. Screening of some medicinal plants for isolation of antifungal proteins and peptides. Pak J Bot 2007; 39(1): 211-221.

[32] Lar PM, Ojile EE, Dashe E, Oluoma JN. Antibacterial activity of Moringa oleifera seed extracts on some Gram-negative bacteria isolates. Afr J Nat Sci 2011; (14): 57-62.

[33] Mann J. Murder: magic and medicine. Oxford Univ Press Oxford 1994; 21(2): 243-259.

[34] Duke JA, Ayensu ES. Medicinal Plants of China. Hough Mif china. 1987; 98(7-8): 398.

[35] Jamdhade MS, Survase SA, Kare MA, Bhuktar AS. Antibacterial activity of genus Datura L. in Marathwada, Maharashtera. J Phyto 2010; 2(12): 42-45.

[36] Akharaiyi FC. Antibacterial, phytochemical and antioxidant activity of Datura metel. Inter J Pharm Tech Res 2011; 3(1): 478-483.

[37] Okwu DE, Igara EC. Isolation, characterization and antibacterial activity of alkaloid from Datura metel Linn leaves. Afri J Pharm Pharmac 2009; 3(5): 277-281.

[38] Prasanna K, Yuwvaranini S. Preliminary phytochemical screening and antibacterial activity of Datura metel and Vitex negundo against bacterial cold water disease causing organism. Inter J Pharm Pharmac Sci 2014; 6(5): 230-233.

[39] Shagal MH, Modibbo UU, Liman AB. Pharmacological justification for the ethnomedical use of Datura Stramonium stem-bark extract in treatment of diseases caused by some pathogenic bacteria. Inter Res Pharma Pharmaco 2012; 2(1): 016-019.

[40] Folch JM, Less M, Sloane-Stanley GH. A Simple method for the isolation and purification of total lipids from animal tissues. J Biol Chem 1957; (226): 497-509.

[41] Abd-Alla AA, Ishak CY, Ayoub SMH. Antimicrobial activity of four medicinal plants used by Sudanese traditional medicine. J Forest Prod Indust 2013; 2(1): 29-33.
[42] Harborne JB. Phytochemical Methods. Chap Hall Pub 1992; pp. 7-8.

[43] Odebiyi A, Sofowora AE. Phytochemical Screening of Nigerian Medicinal Plants. Part III. Lloyida 1990; 234-246.

[44] Fadeyi MG, Adeoye AC, Olowokodejo JD. Epidermal and Phytochemical Studies with genus of Boerhavia (nyctanginaceae). Crude Drug Res 1989; 29: 178-184. http://dx.doi.org/10.3109/13880208909053960

[45] Difco Manual of Dehydration Culture Media and Reagent for Microbiology $\left(9^{\text {th }}\right.$ ed.) Difco labo. Detroit. Michigan 48232, USA; 1984

[46] De Moss RD, Bard RC. Manual of Microbiological methods. Mc Graw Hill Book Company, Inc. New York 1975; 170-171.

[47] Efstratiou E, Hussain Al, Moore JE, Rao JR, Nigam P. Antimicrobial activity of Calendula officinalis petal extracts against fungi as well as Gram-negative and Gram-positive clinical pathogens. Com ther Clin Pract 2012; (18): 173-176.

[48] Balouiri M, Sadiki M, Ibnosuda SK. Methods for in vitro evaluating antibacterial activity. J Pharma Anal 2016; 6(2) 71-79.

http://dx.doi.org/10.1016/j.jpha.2015.11.005

[49] Timothy SY, Wazis FW, Adati RG, Masplama ID. Antifungal activity of aqueous and ethanolic leaf extract of Cassia alata Linn. Int Res J Pharm 2012; 2(7): 182-185. http://dx.doi.org/10.7324/japs.2012.2728

[50] Aiyelaagbe OO, Adeniyi BA, Fatunsin OF, Arimah BD. In vitro antimicrobial activity and phytochemical analysis of Jatropha cucrcas roots. Int J Pharm 2007; 3(1): 421-426.

[51] Rhoades DF. Evolution of plant chemical Defense against Herbivores, their Interaction with secondary plant metabolites. New York, academic Press 1979; 41.

[52] Oluduro OA, Idowu TO, Aderiye BI, Famurewa O, Omoboye OO. Evaluation of antibacterial potential of crude extract of Moringa oleifera seed on oethopaedics wounds isolates and characterization of phenolmethanamine and benzyl isolathiocyanate derivatives. Res J Med Plants 2012; 6: 383394.

http://dx.doi.org/10.3923/rimp.2012.383.394

[53] Nepolean P, Anitha J, Renitta RE. Isolation, analysis and identification of phytochemical of antimicrobial activity of Moringa oleifera. Current Biotica 2009; 3(1): 33-39.

DOI: http://dx.doi.org/10.6000/1927-3037.2016.05.04.4

(c) 2016 Gomaa et al.; Licensee Lifescience Global.

This is an open access article licensed under the terms of the Creative Commons Attribution Non-Commercial License (http://creativecommons.org/licenses/by-nc/3.0/) which permits unrestricted, non-commercial use, distribution and reproduction in any medium, provided the work is properly cited. 